\title{
Rевавсн автіске: Knowledge of the members about working of the self-help groups
}

\section{- RUPATAI D. KADTE, S.U. MOKHALE, N.S. POTE AND B.M. GONSHETWAD}

Article Chronicle: Received :

29.06.2017;

Revised :

25.08.2017;

Accepted :

11.09.2017

Key Words:

Knowledge, SHGs, SHG member's,

Working, Meeting, Extension contact

SUMMARY : The present study was conducted in Amravati district of Maharashtra state. The sample was drawn from the three takula viz., Chandur bazaar, Morshi, Chandur Railway. Thus, 80 SHG member's were selected which constituted the sample respondents for the present study. Data were collected by personally interviewing the respondents with the help of pre-tested structured interview schedule in face to face situation. Collected data were tabulated. Correlation and regression analysis for interpretation of the findings were calculated. Two hypotheses were set for the study and were tested for acceptance or rejection. Results obtained after analysis are summaries as below. In case of personal profile of the SHG members revealed that majority $(53.75 \%)$ of the respondents were middle in age, over $37.5 \%$ were from higher secondary school. Majority $(70.00 \%)$ of respondents belonged to medium category of family income. Majority of $(53.75 \%)$ respondents belonged to nuclear family type. Majority (46.25\%) of the respondents had high level of experience and $52.5 \%$ of respondents belonged to medium level of training received category. Majority (60.00\%) of respondents had medium extension contact. Over half of the $(63.75 \%)$ of the respondents had medium social participation. The findings revealed that majority (71.25\%) of the respondents had medium knowledge about working of the self-help group. Results of the relational analysis revealed that age, education, family income, family type, experience, training received, extension contact showed significant relationship with knowledge and only social participation showed non-significant relationship with knowledge of the SHG member's about working of the selfhelp group.

How to cite this article : Kadte, Rupatai D., Mokhale, S.U., Pote, N.S. and Gonshetwad, B.M. (2017). Knowledge of the members about working of the self-help groups. Agric. Update, 12(4): 548-552; DOI : 10.15740/ HAS/AU/12.4/548-552.
Author for correspondence :

\section{S.U.MOKHALE}

Department of Extension Education, Shri Shivaji Agriculture College, AMRAVATI (M.S.) INDIA

Email:shekharmokhale17 @ gmail.com

See end of the article for authors' affiliations 